\title{
Hubungan Persepsi Remaja tentang Pendidikan Seksual dan Bimbingan Agama Orang Tua dengan Sikap Seksual Remaja pada Siswa SMK Yayasan Pendidikan 17-2 Malang 2016
}

\author{
Yunita Miftahul Masita
}

Fakultas IImu Kesehatan Universitas Islam Jember e-mail : masita.miftahul@yahoo.com

\begin{abstract}
Abstrak
Pemahaman yang kurang tentang seks dapat menimbulkan berbagai efek negative pada kelompok remaja. Pemahaman yang kurang tentang seks edukasi, memicu para remaja untuk mengeksplorasi tentang informasi tentang seks. Bimbingan dan pendidikan keagamaan yang diterapkan dalam keluarga sangat berpengaruh besar terhadap kemampuan penalaran moral yang mengarah pada etika seksual. Berdasarkan data yang diperolah dari Balitbang Pemkab Malang, yaitu CV Orbit Nusantara tercatat 405 pelajar di Kabupaten Malang pernah melakukan sekx bebas. Tujuan penelitian ini adalah untuk tau seberapa pengaruhkah hubungan persepsi remaja tentang pendidikan Sex dan bimbingan Agama dari orang tua dengan sikap seksual remaja pada siswa SMK 17-2 Malang 2016. Menggunakan Desain penelitian Cros sektional. Populasi siswa kelas 1 SMK Yayasan Pendidikan 17-2 Malang. Penelitian ini menggunakan teknik Random sampling dan hasil penelitian menggunakan korelasi ganda yang menunjukkan bahwa Fh 8,257 $\geq F t ~ 3,18$.Terdapat hubungaan antara persespi remaja tentang pendidikan seks dan bimbingan agama dari orang tua dengan sikap seksual remaja. Untuk menghindari sikap seksual yang negatif pada remaja perlu adanya pengarahan tentang pentingnya pendidikan seks dan pengarahan bimbingan keagamaan khususnya bagi orang tua
\end{abstract}

Kata Kunci: Pendidikan Seks, Bimbingan Orang Tua, Sikap Seksual

\begin{abstract}
Lack of understanding abaut sex will lea to a variety og harmful impacts youth group instead. Lack of information abaiut sex makes teenegers trying to find and explore their own acess. Guidance and religious education are applied in the family is very big influence on moral reasoning skills that lead to sexsual ethics. Based on data obtained by the consultant Balitbang Malang Regency, namely CV Net Orbit recorded $40 \%$ of student in the district of malang (East Java)free sex ever done. This study aims to determine the relationship between sex education and relegious guidance of parents and adolesnt sexsual attitudes at SMK Yayasan pendidikan 17- 2 malang. This Study design used was crorss sectional. The Population is first grade student in SMK yayasan Pendidikan 17-2 Malang. Sampling technique used is random sampling of study. This study uses multiple corellation that $\mathrm{FH} 8,257 \geq 3,18 \mathrm{Ft}$. The conclustion is there a relationshi between perception of adolescents abaout sex education and relegious guidane of parents with adolescent seksual behavior. To avoid nagtive sexsual attitudes in teenagers need the guidance of the importance of sex education, religious guidance and direction, especially for parents.
\end{abstract}

Keyword: Sex Education, Parents Guidance Relegion, Sexsual Attitudes

\section{Pendahuluan}

Masa remaja merupakan masa dimana rasa penasaran pada permasalahan yang berhubungan dengan seksual sangat tinggi. Hal ini erat kaitanya, didalam terwujudnya relasi yang lebih matang terhadap lawan jenisnya. Di masa remaja pengetahuan tentang masalah yang berhubungan dengan seksualitas sejatinya sudah mulai dipaparkan, hal ini bertujuan untuk meminilmalisir para remaja untuk mencari informasi dari sumber yang salah. Menginformasikan permasalahan tentang seks sangatlah penting, karena seperti yang kita tau remaja berpotensi menjadi seksual aktif, hal ini berhubungan dengan hasrat sek yang berhubungan dengan pematagan hormon serta mereka tidak mempunyai informasi yang cukup tentang aktifitas seks pada remaja (Handbook of
Adolecent psychology, 2000).

Kurangnya pemahaman tentang kesehatan reproduksi bisa mengakibatkan dampak yang buruk pada kalangan remaja. seperti yang kita ketahui jumlah penduduk didunia ini yaitu berkisar 6,3 miliar jiwa dan sekitar 1 milyar dari populasi tersebut adalah remaja. populasi remaja di Indonesia pada tahun 2000 yaitu berkisar 43,3 \% (rentan usia 15- 20 tahun) dan jumlah tersebut meningkat $29 \%$ pada tahun 2003 dari total jumlah penduduk Indonesia sekitar 210 juta jiwa. 70 $\%$ wanita dan $80 \%$ lelaki Indonesia melakukan hubungan seks dimasa pubertasnya. di Indonesia, bahkan $20 \%$ dari mereka memiliki pasangan lebih dari satu. Kurang Lebih 53 \% wanita kisaran usia 15 19 tahun pernah melakukan hubungan seksual di masa remaja, sedangkan jumlah lelaki yang 
pernah melakukan hubungan seks lebih banyak daripada jumlah wanita (Wahyurini,2004).

Yayasam Pelita IImu Jakarta melakukan survey pada remaja berusia 13 - 20 tahun. Hasil yang didapat adalah $42 \%$ responden mengakui pernah melakukan hubungan seks, dan selebihnya masih aktif melakukan hubungan seks dalam kurun waktu 1 - 3 bulan terakhir. Para remaja mungkin harus menanggung beban yang berat seperti kehamilan yang tidak diinginkan, dimana permasalah ini bisa mengarah pada tindakan mengakhiri kehamilan dengan cara yang berbahaya. Di Provinsi Jawa Timur dilakukan penelitian yang dengan hasil 9,8\% dari 41 remaja pernah melakukan aborsi dan $8 \%$ pernah mengantar temannya untuk melakukan aborsi. Hasil penelitian yang dilakukan pada tahun 2000-2003, didapatkan bahwa dari 37000 kasus Kehamilan Tidak Diinginkan (KTD), sekitar $27 \%$ diantaranya dialami oleh wanita single, termasuk $12,5 \%$ diantaranya masih berstatus sebagai pelajar dan mahasiswa. (Suhadianto, 2006).

Perkembangan teknologi dan mulai terjadinya peregeseran budaya di Kota Malang ternyata membawa efek negative. Sebagian mahasiswa yang ditemui di rumh kost mengaku, pernha melakukan seks bebas. Mereka mengaku terinspirasi, karena seringnya melihat adegan tak senonoh dan melakukan hal tersebut dengan pacar mereka. Penelitian yang pernah dilakukan disalah satu SMK negeri terdapat $7,4 \%$ siswa yang mempunyai persepsi negatif terhadap persepsi seksual, dan juga survey yang dilakukan pada remaja SMP seKecamatan Klojen menunjukkan beberapa siswa yang masih mempunyai pemahaman yang salah tentang perilaku seksual, hasil riset yang dilakukan oleh konsultan Balitbang Pemkab Malang, yaitu CV Orbit Nusantara, didapatkan 40\% pelajar di Kabupaten Malang (Jatim) pernah melakukan seks bebas.

Adanya pemahaman bahwa berbicara tentang seks adalah hal yang tabu, membuat para remaja tidak mau berdiskusi perihal kesehatan reproduksi. Satu hal yang menjadi permasalahan kebanyakan para remaja enggan membicarakan tentang seksualitas (permasalaahan kesehatan repoduksi) dengan anggota keluarganya sendiri. Mereka merasa tidak nyaman bila membahas permasalahan tersebut dengan keluarganya.

Minimnya informasi tentang seksualitas, memicu remaja untuk mencari informasi tentang seks. Sehingga informasi yang mereka dapat tidak dapat tersaring secara benar, sehingga info yang mereka dapat, adalah hal yang kurang tepat tentang seksualitas. Informasi yang salah tentang seksualitas membuat persespi dan pengetahuan mereka tentang seksualitas itu menjadi tidak benar.

Permasalahan ini menjadi salah satu indicator meningkatnya prevalensi perilaku seks bebas dilakalangan remaja. Tingkat pemahaman yang kurang, justru lebih mengkhwatirkan, daripada tidak tahu sama sekali, kendati didalam hal ini ketidaktahuan juga memiliki resiko para remaja melakukan kegiatan seks yang beresiko.

Pendidikan seksual dapat diperoleh dari pendidikan formal dan nonformal. Pendidikan seksual, selain menerangkan aspek biologis dan anatomi tubuh manusia, juga menjelaskan tentang aspek moral dan psikis. Dalam pendidikan seks yang benar harus memasukan unsur tentang HAM (Hak Asasi Manusia) serta nilai agama dan budaya. Kartono memaparkan (1991), edukasi tentang pemahaman seksualitas yang tepat bertujuan untuk menjadikan orang tua yang memiliki rasa tanggung jawab dan dapat membina keluargnya dengan baik dan benar.

Para ahli berpendapat pemberian edukasi tentang seks harus disisipi dengan unsur etika dan moral, serta hubungan dengan sesama manusia dalam bersosialisasi. Edukasi tentang seks bukan hanya bertujuan untuk menimbulkan penasaran dan rasa untuk ingin mencoba tentang hubungan seks akan tetapi lebih mempersiapkan pemahaman para remaja agar lebih mengetahui tentang kesehatan reproduksi. Dengan adanya edukasi tentang seks yang benar dan tetap diharapkan para remaja bisa mengetahui dampak negatif dari seks bebas dan para remaja dapat berkelakuan yang baik sesuai dengan adat istiadat, norma agama, kesusilaan dan norma sosial. (Tirto Husodo, 2007).

Bimbingan dan pendidikan keagamaan yang diterapkan dalam keluarga sangat berpengaruh besar terhadap kemampuan penalaran moral yang mengarah pada etika seksual, sehingga dengan landasan moral keagamaan yang ditanamkan oleh keluarga akan mengarah pada perilaku seksual aman dan bertanggung jawab dan akan terhindar dari perilaku seksual menyimpang. Bimbingan agama memberikan arah agama yang haq yang membuat manusia menghormati kebenaran dan berjalan menuju arahNya, mencintai keindahan dan mengagungkan Nya.( Tafsir,2007).

Berdasarkan studi pendahuluan di SMK Yayasan Pendidikan 17-2 di Malang dari 7 siswa, pernah melakukan kegiatan berpacaran, berciuman bibir, meraba bagian 
tubuh pacar, masturbasi dan berpegangan tangan. Menurut pemaparan yang disampaikan oleh guru bimbingan konseling, 40\% siswa di SMK tersebut adalah lulusan pondok pesantren dan madrasah sanawiyah yang notabenya merupakan pendidikan yang berlandasan keagamaan. Salah satu hal yang perlu dipamahami adalah apa yang dipikirkan seseorang, akan dialami oleh orang tersebut dan bagaiman seseorang mempersepsikan sesuatu akan menentukan tindakan dan sikapnya terhadap objek persepsi (Satiadarma,2001). Berdasarkan fenomena tersebut maka perlu dilakukan penelitian mengenai " Hubungan Persepsi Remaja Tentang Pendidikan Seksual dan Bimbingan Agama Orang Tua dengan Sikap Seksual Remaja pada Siswa SMK Yayasan Pendidikan 17- 2 Malang.

\section{Metode Penelitian}

Pada penelitian ini menggunakan desain penelitian korelasional, merupakan penelitian yang mengkaji hubungan antara variabel yaitu hubungan persepsi remaja tehadap pendidikan seks dan bimbingan agama dari orang tua dengan sikap seksual remaja. Jenis penelitiannya menggunakan pendekatan penelitian cross sectional, yaitu dengan pengukuran ketiga variabel secara bersamaan di SMK Yayasan Pendidikan 17-2 Malang

Tempat : SMK Yayasan Pendidikan 17-2 Malang. Waktu penelitian : Bulan Mei - Juni 2016. Pada riset ini menggunakan sejumlah 60 siswa kelas 1 di SMK Yasasan Pendidikan 17 - 2 Malang , yang digunakan sebagai populasi.

Sampel pada penelitian ini yaitu siswa kelas 1 di SMK Yayasan Pendidikan 17-2 Malang sejumlah 52 orang.

\section{Hasil Dan Pembahasan}

Hasil

Hasil Analisa dengan Menggunakan Uji Product Moment. Untuk menguji adanya hubungan antara persepsi pendidikan seks, bimbingan agama dan sikap seksual remaja di SMK Yayasan Pendidikan 17-2 Malang menggunakan Product Moment. Pengujian dilakukan dengan menggunakan SPSS ver 16.

Untuk uji korelasi hubungan persepsi remaja tentang pendidikan seks dengan sikap seksual remaja didapatkan nilai $r$ hitung adalah 0,397 lebih besar dari $r$ tabel dengan $n=52$ adalah 0,279 , dengan nilai signifikansi $(p) 0,01$ yang lebih kecil dari alpa 0,05 , yang berarti hubungan persepsi remaja tentang pendidikan sek dengan sikap seksual remaja signifikan (bermakna).

Dalam uji korelasi antara hubungan persepsi bimbingan agama dari orang tua dengan sikap seksual remaja didapatkan nila $r$ hitung adalah 0,413 lebih besar dari $r$ tabel dengan $n=52$ adalah 0,229 , dengan nilai signifikansi $(p) 0,01$ yang lebih kecil dari alpa 0,05 , yang berarti hubungan persepsi bimbingan agama dari orang tua dengan sikap seksual remaja signifikan(bermakna).

Nilai dari $r$ hitung pada variabel persepsi remaja tentang pendidikan seks dan bimbingan agama dari orang tua positif, maksudnya dengan adanya persepsi positif tentang pendidikan seks dan bimbingan agama dari orang tua maka akan semakin negative sikap seksualnya pada remaja SMK Yayasan Pendidikan 17-2 Malang. Demikian juga sebaliknya jika persepsi negative terhadap pendidikan seks dan bimbingan agama dari orang tua maka semakin positif sikap seksualnya.

Hasil Analisa Menggunakan Uji Korelasi Berganda. Pengujian selanjutnya untuk mengetahui adanya hubungan persepsi remaja tentang pendidikan seks dan bimbingan agama dari orang tua dengan sikap seksual remaja pada siswa SMK Yayasan Pendidikan 17-2 Malang dengan menggunakan uji korelasi ganda dengan rumus korelasi ganda (lampiran ) didapatkan nilai koefisien korelasi $F$ hitung adalah 7,85 . Sedangkan nilai $F$ tabel dengan taraf signifikansi 0,05 adalah 3,18 . Hal ini menunjukkan bahwa nila $F$ hitung lebih besar gari $\mathrm{F}$ tabel sehingga hipotesis $\mathrm{H} 1$ diterima yang berarti adanya signifikansi antara hubungan persepsi remaja tentang pendidikan seks dan bimbingan agama dari orang tua dengan sikap seksual remaja.

\section{Pembahasan}

Hubungan Persepsi Remaja Tentang Pendidikan Seks Dengan Sikap seksual Remaja.

Hasil uji analisa terhadap persepsi remaja tentang pendidikan seks dengan sikap seksual remaja pada siswa SMK Yayasan Pendidikan 17-2 Malang di dapatkan adanya hubungan antara persepsi remaja tentang pendidikan seks dengan sikap seksual remaja. Dapat jelaskan bahwa siswa yang mempunyai peresepsi positif terhadap pendidikan seks mempunyai sikap seksual yang negative dan siswa yang memiliki persepsei yang negative terhadap pendidikan seks memiliki sikap seksual yang positif. Pada penelitian ini didapatkan usia siswa yaitu usia $15-16$ tahun, yamg merupakan remaja pertengahan (Soetjiningsih,2004) .

Pada usia remaja menengah, para remaja telah terjadi maturitas fisik secara keseluruhan, pendapat ini dikemukakan oleh Andini bahwa pada fase ini gairah seks pada remaja sedang pada fase tertinggi sehingga, pada fase ini para remaja memiliki kecenderunngan untuk mencoba melakukan sentuhan fisik, akan tetapi perilaku sexual mereka masih wajar secara alamiah. pria berusaha mencari perlindungan dengan membebaskan diri dari kenyataan (Andini 2008). Menurut hasil penelitian di dapatkan hasil bahwa para siswa mendapatkan pendidikan tentang seks dari, guru disekolah sebesar $7 \%$ orang tua sebesar $11,5 \%$ dan 
media cetak (buku, majalah, tabloid) sebesar $21,1 \%$ dan media elektronik sebanyak $42,3 \%$. Siswa yang memiliki persepsi positif tentang pendidikan seks rata-rata mendapatkan informasi tentang seks dari sumber-sumber yang bertanggung jawab seperti informasi dari guru disekolah, orang tua ,buku pelajaran disekolah, sedangkan yang mempunyai persepsi negative tentang pendidikan seks mereka mendapat informasi yang kurang tepat tentang pendidikan seks yaitu mereka dapat dari teman sebaya dan media cetak maupun elektronik tanpa adanya arahan yang tepat, sehingga mereka mempunyai anggapan yang negative tentang pendidikan seks dan mempersepsikan bahwa pendidikan seks tersebut hanya seputar pornografi saja. Seperti yang kita ketahui saat ini sangat mudah sekali mendapatkan konten-konten "dewasa" yang sangat mudah didapat terutama dari media sosial, dengan semakin banyaknya pengetahuan yang tanpa batas, bisa mengubah peradigma remaja mengenai seks dan seksualitas.

Lingkungan sekolah dan keluarga adalah lokasi yang benar bagi remaja guna memperoleh pengetahuan yang benar tentang edukasi seksual, karena remaja mengambil contoh dari perilaku orang tua dan orang lain di lingkungan sekitarnya. Sesuai dengan pendapat yang dikemukakan oleh sarlito bahwa pendidikan seks tidak diberikan secara fulgar, tetapi diberikan secara "konstekstual", yaitu dalam berkaitan dengan norma yang ada dalam masyarakat, hal hal apa saja yang tidak diperbolehkan, apa yang wajar dan bagaimana cara menjalankanya tanpa melanggar hukum. Tidak bisa dipungkiri permasalah tetang seks merupakan masalah yang tabu untuk dibicarakan dikalangan orang dewasa apalagi dengan remaja dan anak anak. Akan tetapi hal yang perlu disadari adalah orang tua merupakan pendidik yang paling baik bagi anak anaknya, orang tua merupakan panutan bagi buah hatinya. Apabila remaja tersebut tidak diberikan pendidikan seksual secara dini oleh orang tauanya dan mereka berusaha mencari tau sendiri dari sumber sumber yang tidak bertanggung jawa, maka hal tersebut dapat menjerumuskan mereka dalam hal hal yang tidak dinginkan.

Hubungan Bimbingan Agama dari orang tua dan sikap seksual remaja

Berdasarkan hasil analisa data didapatkan korelasi antara persepsi remaja tentang bimbingan agama dari orang tua dengan sikap seksual remaja didapatkan bahwa jika mereka mempunyai persepsi positif tentang bimbingan agama dari orang tua maka mempunyai sikap seksual yang positif, sesuai dengan analisa data yang di peroleh bahwa 53,8\% ini di sebabkan karena sebagian besar siswa tinggal dirumah dan tinggal bersama orang tua mereka, hal ini sesuai dengan teori bahwa bimbingan dan pendidikan keagamaan yang diterapkan dalam keluarga sangat berpengaruh besar terhadap kemampuan penalaran moral yang mengarah pada etika seksual, sehingga dengan landasan moral keagamaan yang ditanamkan oleh keluarga akan mengarah pada perilaku seksual aman dan bertanggung jawab dan akan terhindar dari perilaku seksual menyimpang. Bimbingan yang diberikan dari orang tua dapat mengarahkan pada etika seksual yang bertanggung jawab. Pada masa remaja, mereka mempunyai sifat kritis terhadap ajaran agama (Gufron,2011), oleh karena itu orang tua berperan penting sebagai pendidik utama bagi putra-putri mereka, sehingga mereka mengerti apa-apa yang diperbolehkan serta dapat mengarahkan mereka pada sikap seksual yamg bertanggung jawab sesuai dengan tahap perkembangan usia mereka.

Hubungan Persepsi tentang pendidikan seks dan bimbingan agama dari orang tua terhadap sikap seksual remaja

Berdasarkan hasil analisa data menggunakan Korelasi berganda didapatkan hubungan antara persepsi remaja tentang pendidikan seks dan bimbingan agama dari orang tua dengan sikap seksual remaja tingkat hubungan yang positif. Hal ini berarti persepsi terhadap pendidikan seks dan bimbimgan agama dari orang tua memiliki hubungan searah dengan sikap seksual remaja. Maksudnya jika memiliki persepsi positif terhadap pendidikan seks dan bimbingan agama dari orang tua maka memiliki sikap seksual yang negative, dan dipeoleh Fhitung 7,997 >Ftabel 3,18 maka H1 diterima. Dengan demikian maka ada hubungan yang signifikan antara persepsi remaja terhadap pendidikan seks dan bimbingan agama dari orang tua dengan sikap seksual remaja di SMK Yayasan Pendidikan 17-2 Malang. Hal ini disebabkan karena landasan etika seksual yang bertanggung jawab didapatkan dari penaman dan bimbingan keagamaan yang didapat dari orang tua, karena orang tua merupakan pendidik utama bagi putra-putri mereka sesuai dengan teori bahwa merosotnya pemahaman keagaamaan pada remaja menyebabkan adanya perilaku seksual yang beresiko dan bertentangan dengan agama (Sarwono, 2006), sehingga bimbingan yang diberikan sangat berperan penting dalam perkembangan moral anak. Pendidikan seksual yang didapat remaja harus diarahkan sesuai dengan tahap perkembangan usia mereka dan melalui 
arahan -arahan yang benar. Berdasarkan hasil penelitian para remaja memiliki persepsi positif terhadap pendidikan seks dan bimbingan agama dari orang tua kerena mereka memperoleh informasi tentang seks dari sumber - sumber yang bertangguang jawab, dan sebagian memiliki persepsi negative karena mereka mendapatkan sumber-sumber yang kurang tepat tanpa adanya arahan dan mereka rata-rata tidak tinggal bersama orang tua mereka (kost), sehingga control yang didapat dari orang tua sangat kurang. Seperti yang kita ketahui remaja memiliki rasa penasaran yang tinggi, mereka cenderung ingin mencari informasiinformasi yang dianggap baru oleh mereka.

Di usia remaja menengah, sudah terjadi pematangan fisik. Pada masa remaja menengah hasrat sexsual remaja telah berada pada puncaknya, hal ini menyebabkan mereka cenderung melakukan sentuhan fisik (Soetjiningsih, 2004). Salah satu ciri masa remaja adalah sebagai fase transisi, dari fase anak ke fase dewasa. Di awal fase dewasa, sebagian perilaku remaja kerap kali melakukan hal hal yang mereka anggap sebagai awal mula dari fase dewasa seperti dewasa merokok, minuman keras, obat terlarang terlibat seks bebas, agar mereka memdapatkan jati diri yang mereka inginkan (Hurlock, 1999), oleh sebab itu pemahaman tentang pentingnya pendidikan seks dan bimbingan keagamaan sangat perlu ditekankan untuk membentuk moral yang baik , etika seksual yang bertanggung jawab dan menerima perubahan yang terjadi pada tubuhnya.

\section{Kesimpulan Dan Saran}

Kesimpulan

1. Dari 52 responden diperoleh 55,7\% (29 siswa) rmemiliki persepsi positif tentang pendidikan seks dan 44,3\% (23 siswa) memiliki persepsi negatif tentang pendidikan seks.

2. Dari 52 responden, diperoleh $53,8 \%$ (28 siswa) memiliki persepsi positif terhadap bimbingan agama dari orang tua dan 46,2\% (24 siswa) memiliki persepsi negatif tentang bimbingan agama dari orang tua.

3. Dari 52 responden, diperoleh $78,8 \%$ (41 siswa) memiliki persepsi negatif tentang pendidikan seks dan $21,2 \%$ (11 siswa) memiliki persepsi positif tentang pendidikan seks.

4. Dari analisa korelasi ganda dengan $F$ hitung = 7,997 kemudian dikonsultasikan ke $\mathrm{F}$ tabel dengan taraf kesalahan $5 \%$ dan $\mathrm{N}=52$, maka harga $F$ tabel $=3,18$. Harga $F$ hitung lebih besar dari pada harga $F$ tabel, sehingga ho ditolak dan ha diterima , hal ini berarti ada Hubungan persepsi remaja tentang pendidikan seks dan bimbingan agama dari orang tua dengan sikap seksual remaja di SMK Yayasan Pendidikan 17-2 Malang.

Saran

Bagi peneliti selanjutnya diharapkan tidak mengulangi keterbatasan atau kekurangan yang peneliti lakukan selama penelitian dan selanjutnya mampu melakukan penelitian yang lebih baik. Saran yang diberikan bagi pihak sekolah harus lebih intens memberikan informasi yang tetap, yang berfokus pada peserta didik, tentang kespro khususnya perilaku seksual yang dapat membahayakan kesehatan para remaja. edukasi seperti ini layaknya disampaikan melalui cara yang profesional dan tepat. Berbagai program yang berkenaan dengan kesehatan reproduksi agar lebih bersinergi dalam rangka pencegahan dan dilakukan melalui kerja sama di tingkat sekolah. Program edukasi seksual disekolah diharapkan bisa memberikan informasi mengenai pentingnya kesehatan reproduksi. Sehingga dapat meningkatkan pemahaman, sikap dan tingkah laku yang sesuai bagi para remaja. peran serta masyarakat dan lingkungan sekitar sangat mempengaruhi terhadap terwujudnya pengetahuan tentang kesehatan reproduksi yang baik dan benar yang sesuai dengan perkembangan remaja. Contohnya dilakukanya pemberian informasi secara rutin dan berkala pada murid mengenai permasalah yang berhubungan dengan kesehatan reproduksi, dan menambah pemahaman orang tua murid terhadap dampak perilaku seksual beresiko pada kesehatan reproduksi remaja, ditengah. Peran orang tua dalam hal menanamkan pemahaman dan bimbingan spiritual juga harus ditingkatkan untuk membentuk moral dan etika anak menjadi lebih bertanggung jawab..

\section{Daftar Pustaka}

Ahmad, Furkon. 2005. Konsep dan Aplikasi Bimbingan Konseling di Sekolah dasar. Bandung: CV Bani Quraisy.

Andini, Putu Sri. 2008. Perbedaan Sikap Terhadap Perilaku Sex Maya Berdasarkan Jenis Kelamin Pada Dewasa Awal. Skripsi. Jakarta: Universitas Gunadarma.

Bimbingan dan Konseling 2009. Diakses tanggal 3 januari 2016. http://Imronfauzi.wordpress.com.htm .

Daradjat, Zakyah (2004). IImu Pendidikan 
Islam.Jakarta : Bumi Aksara.

Determinan Persepsi .2011. Diakses tanggal 2 januari 2016 http://rumahbelajarpsikologi.com/index.ph p/pengaruhi-persepsi.html>

Gufron,M. Nur \& Risnawati, Rini. 2010. Teoriteori Psikologi. Jogjakarta: Ar Ruzz Media.

Hadikusumo, K. 2006. Pengertian Orang Tua. Diakses tanggal januari 2016. http://www.aryesnovianto.com

Hidayat, Alimul. 2009. Metode Penelitian kebidanan Teknik Analisa Data. Jakarta: Salemba Medika

Hidayat,komarudin. 2009. The Wisdom of Life. Jakarta: Erlangga

Hurlock, Elizabeth. 1999. Psikologi Perkembangan. Jakarta : Erlangga.

http:// Pendidikan Seksual PadRemaja at ILMU PSIKOLOGI INDONESIA.htm > . Di akses tanggal 7 januari 2016.

Ilham,A 2009. Pengertian Bimbingan Konseling Agama. Di akses tanggal 8 januari 2012. http://pengertian-bimbingankonseling-agama.com $/ \mathrm{html}$.

Josep Adelson 1989. Handbook of Adolecent psychology. Di akses 3 Januari 2012 .http://

Handbook_of_adolescent_psychology.ht $\mathrm{ml}$.

Konsep Perilaku Remaja. 2001. Diakses tanggal 4 januari 2016. http://www.konsepperilaku.notoatmdjo.com.

Microsoft encarta encyclopedia 2002 Di akses tanggal 5 januari 2016.http://zifoe.com/2010/06/freeencarta-encyclopedia-2009.html.

Notoatmodjo,S.2007.IImu Masyarakat. Jakarta: Rineka Cipta

Notoadmodjo, Soekidjo.2010. Metodelogi Penelitian Kesehatan. Jakarta: Rineka Cipta

Nursalam. 2008. Konsep dan Penerapan Metodologi Penelitian IImu Keperawatan. Jakarta: Salemba Medika.

Pendidikan Seks Upaya Preventif terhadap perilaku seksual remaja 2006 .Diakses 7 januari 2016 . http://www.Suhadianto.com

Pengertian Pendidikan Seks dan Manfaatnya. Diakses tanggal 7 januari 2012. http://duniabaca.com/.html.

Rosyidan 2009. Pengertian Bimbingan Konseling Agama. Di akses tanggal 8 januari 2012. http://pengertian-bimbingankonseling-agama.com $/ \mathrm{html}$

Sarwono, Sarlito.2002.

Psikologi Remaja.Jakarta : PT Raja Grafindo Persada

Soetjiningsih.2004.Tumbuh Kembang Remaja
Dan Permasalahannya.Jakarta: CV. Sagung Seto.

Sugiyono. 2009. Statistik Untuk Penelitian. Bandung : Alfabeta

Supriyanto, T. 2009. Humanistis Spiritual dalam Pendidikan.Malang: UIN-Malang Press.

Tafsir, Ahmad .2007. Ilmu Pendidikan dalam Perspektif Islam, Bandung: Rosda.

Walgito, Bimo. 2003. Pengantar Psikologi Umum. Yogyakarta: Andi.

Widiyatun,R.1999. IImu Perilaku Jakarta: PT.Fajar Interpratama.

Wikipedia. 2000 .Pengertian Persepsi. Diakses tanggal 5 Januari 2016. http://id.wikipedia.org/wiki.

Wikypedia. 2000 .Perilaku manusia. Diakses tanggal 5 Januari 2016. http://id.wikipedia.org/wiki.

W.S, Winkel, 1991, Bimbingan dan Konseling di Institusi Pendidikan, Jakarta : PT Grasindo.

Yusuf, Samsu dan Nurishan, A. Juntika, 2006. Landasan Bimbingan dan Konseling, Bandung : Remaja Rosdakarya. 